DOI: https://doi.org/10.18371/fp.3(39).2020.215178

УДК 338.1:336.27

\title{
КРЕДИТНИЙ КАНАЛ ТРАНСМІСІЙНОГО МОНЕТАРНОГО MЕХАНІЗМУ ТА ЙОГО МІСЦЕ В ЕКОНОМІЧНОМУ ЗРОСТАННІ
}

\author{
КОВАЛЕНКО Вікторія Володимирівна \\ д.е.н., професор, \\ професор кафедри банківської справи, \\ Одеський національний економічний університет \\ ORCID ID: http://orcid.org/0000-0003-2783-186X \\ e-mail: kovalenko-6868@ukr.net
}

\begin{abstract}
Анотація. У статті висвітлені проблеми дієвості кредитного каналу трансмісійного монетарного механізму та звернено увагу його впливу на економічне зростання держави. Проаналізовано сучасний стан кредитування реального сектору економіки. Запропоновано основні напрями підвищення дієвості кредитного та процентного каналів монетарного трансмісійного механізMy.

Ключові слова: кредитний канал, процентний канал, монетарний трансмісійний механізм, економічне зростання, реальний сектор економіки, кредитування, прочентні ставки.
\end{abstract}

Постановка проблеми. Економічне зростання держави залежить впершу чергу від динамічного розвитку реального сектору економіки, та оцінюється за допомогою виробленого валового внутрішнього продукту. При цьому, слід відмітити, що для розвитку реального сектору завжди потрібні додаткові джерела фінансування, які мають форму кредитних ресурсів банківської системи. Особливої актуальності ця проблема набуває в умовах пошуку шляхів стабілізації економічного розвитку в країнах, де економіка знаходиться на стадії посткри-
Аннотация. B cтатье освещуены проблемbl действенности кредитного канала трансмиссионного монетарного механизма и обрашено внимание его влияния на экономический рост государства. Проанализировано современное состояние кредитования реального сектора экономики. Предложень основные направления повышения действенности кредитного и процентного каналов монетарного трансмиссионного механизма.

Ключевые слова: кредитный канал, процентный канал, монетарный трансмиссионный механизм, экономический рост, реальный сектор экономики, кредитование, процентные ставки.

зового синдрому, відсутності сталих темпів зростання реального сектору економіки, порушень взаємовідносин у фінансовій та соціальноекономічних сферах [1, с.445]. Тому, актуалізується питання підвищення дієвості кредитного каналу трансмісійного монетарного механізму 3 зору доступності кредитних ресурсів та їх сприяння у досягненні стратегічних цілей сталого економічного зростання України.

Аналіз останніх досліджень та публікацій. Дослідженню питання впливу кредитного каналу монетарно- 
го трансмісійного механізму на економічне зростання держави присвячено наукові праці як зарубіжних, так i вітчизняних вчених. Так, визначення основних постулатів економічного зростання держав розглядається у працях Т. Єфименко [2], М. Звєрякова [3], Н. Мінакової [4], В. Міщенка [5].

Т. Єфименко відзначає, що «...в умовах нової економічної реальності, загроз виникнення нових кризових ситуацій, особливої актуальності для всіх регіонів та країн світу набуває здатність національних економік до стабільного розвитку» [2, с. 10].

М. Звєряков наголошує на тому, що «...вихід 3 нинішніх труднощів і перехід на траєкторію сталого розвитку можливі на основі нової соціальноекономічної моделі, де розширене відтворення можливе на підприємствах реального сектору економіки» [3, с. 25].

При цьому, слід відзначити, дослідження Мінакової Н., яка наголошує на тому, що в поняття «сталий розвиток» закладаються різні аспекти його трактування. У країнах $з$ ринковою економікою, що розвиваються, цей термін використовують при виробленні програм сталого економічного зростання, то у світі в цілому, під сталим розвитком розуміється набагато фундаментальний, збалансований розвиток економічних, соціальних та екологічних компонент [4, с. 59-60].

Проблема підвищення дієвості кредитного каналу трансмісійного монетарного механізму та його впливу на економічне зростання досліджується у наукових працях Бернанке Б. [6], Асангу С. [7], Прасолової С. [8], Кириченко К. [9], Петрика О. [10] та багатьох інших. Шануючи доробок зазначених вчених, слід відмітити, що залишаються поробленими питаннями урегулювання кредитних відносин щодо їх форм та інструментів; зменшення процентних ставок за наданими кредитами реальному сектору економіки 3 метою підвищення дієвості кредитного каналу трансмісійного монетарного механізму.

Метою статті $\epsilon$ обгрунтування сутності кредитного каналу трансформаційного монетарного механізму та формулювання пропозицій щодо підвищенні його дієвості для економічного зростання держави.

Виклад основних результатів. Визначальна роль кредитного каналу трансмісійного монетарного механізму в економічному зростанні держави визначено у Законі України «Про банки i банківську діяльність» від 07.12.2000 № 2121-III [11], де визначено, що основним завданням банків в механізмі фінансового посередництва, $\epsilon$ надання банківських послуг щодо акумуляції вільних коштів юридичних i фізичних осіб та спрямування цих коштів економічним суб'єктам, які їх потребують. При цьому слід зазначити, що головна роль банків у економічній системі держави полягає в кредитуванні економіки, тобто в наданні економічним суб'єктам додаткових фінансових ресурсів із метою здійснення їхньої основної діяльності. Кредит покликаний забезпечити фінансування нових капітальних інвестицій, купівлі фінансових і нефінансових активів та збільшення споживання й фінансування [12, с. 8].

Як зазначає авторка статті, грошово-кредитна політика має розглядатися як джерело економічних зрушень, підвищення реальної заробітної плати i, відповідно, рівня життя населення; виступає засобом стримування ін- 
фляційних процесів, що, в свою чергу, відповідає стратегічним цілям грошово-кредитної політики [13, с. 9].

Національний банк України, використовуючи належні йому монетарні інструменти, має змогу впливати на основні показники економічного зростання в державі. Представлений вплив здійснюється не прямо, а через складний економічний механізм, який має назву трансмісійного механізму монетарної політики. В цілому економічну категорію «монетарний трансмісійний механізм» визначають як відносини 3 приводу впливу на використання інструментарію грошово-кредитної політики центрального банку на фінансову кон'юнктуру і в подальшому - на макроекономічні змінні, які відображають стан розвитку реального сектора економіки через складну сукупність каналів та зв'язків прямої і зворотної дії [14, с. 11-13].
На погляд Міщенка В., більш практичним і наближеним до діяльності центрального банку можна вважати визначення такого механізму як системи взаємозв'язків, що відображає, яким чином дії монетарної влади впливають на досягнення операційних, проміжних і стратегічних цілей монетарної політики. Монетарний трансмісійний механізм не є самоціллю, він функціонує в рамках монетарного режиму, для котрого характерні певні правила й операційні процедури, а кінцевою метою є забезпечення центральним банком цінової стабільності $[15$, c. 32].

У загальному вигляді схему монетарного трансмісійного механізму можна подати у вигляді впливу інструментів грошово-кредитної політики, що використовуються, основних параметрів розвитку фінансового ринку та реального сектора економіки (рис. 1).

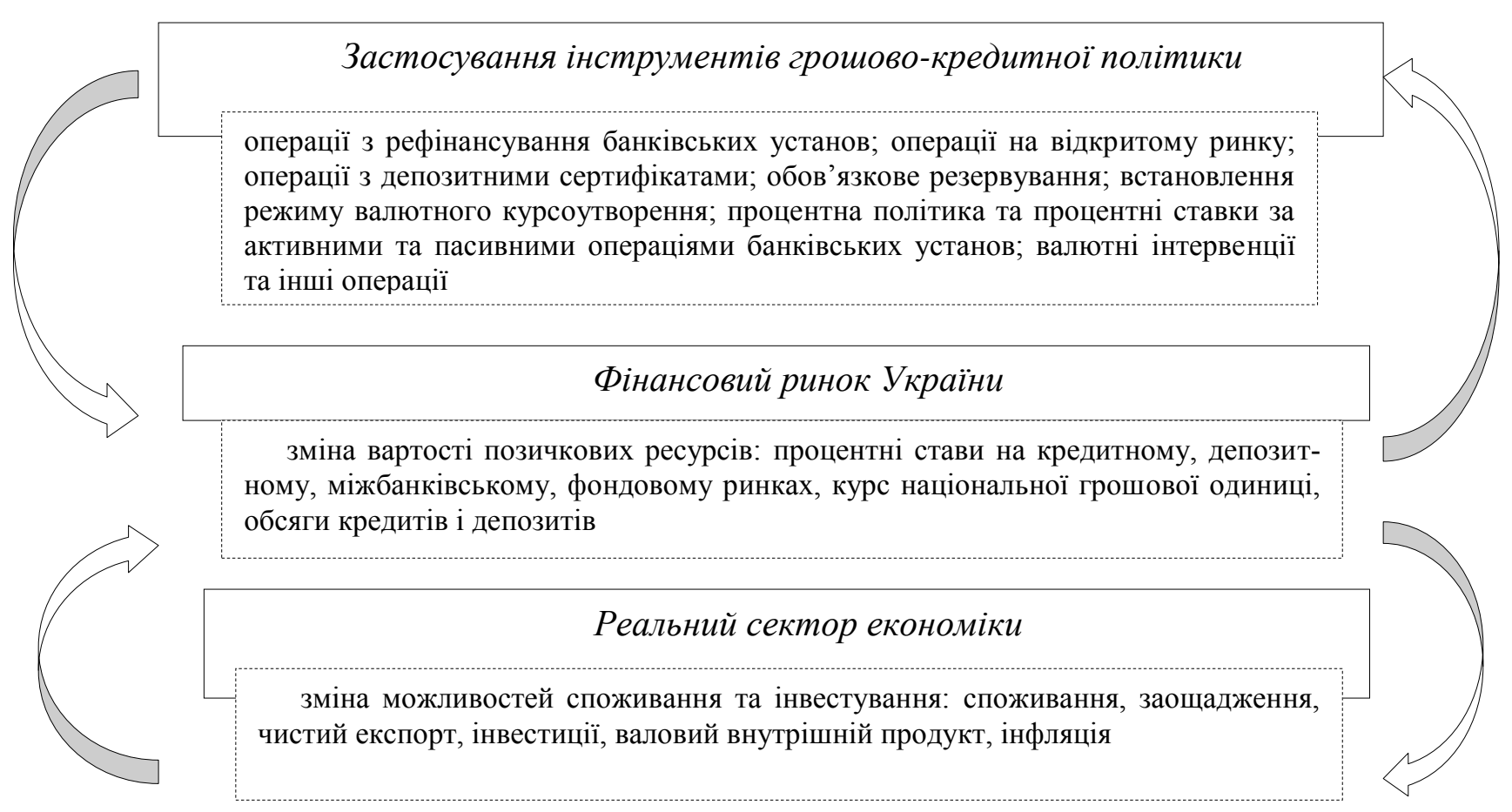

Рис. 1. Сфери дії трансмісійного механізму грошово-кредитної політики Джерело: власна розробка автора 
Виходячи із представленого рисунку, ми можемо стверджувати, що кредитний канал монетарного трансмісійного механізму займає провідне місце у забезпеченні економічного зростання в державі. Кредитний канал відображає вплив грошово-кредитної політики центрального банку на доступність ресурсів на кредитних ринках шляхом впливу інструментів гро- шово-кредитної політики на зміну пропозиції кредитних ресурсів через зміну обсягів вільних резервів банківської системи.

Схема дії каналів механізму монетарної трансмісії та їх вплив на основні індикатори макроекономічного зростання представлено на рис. 2.

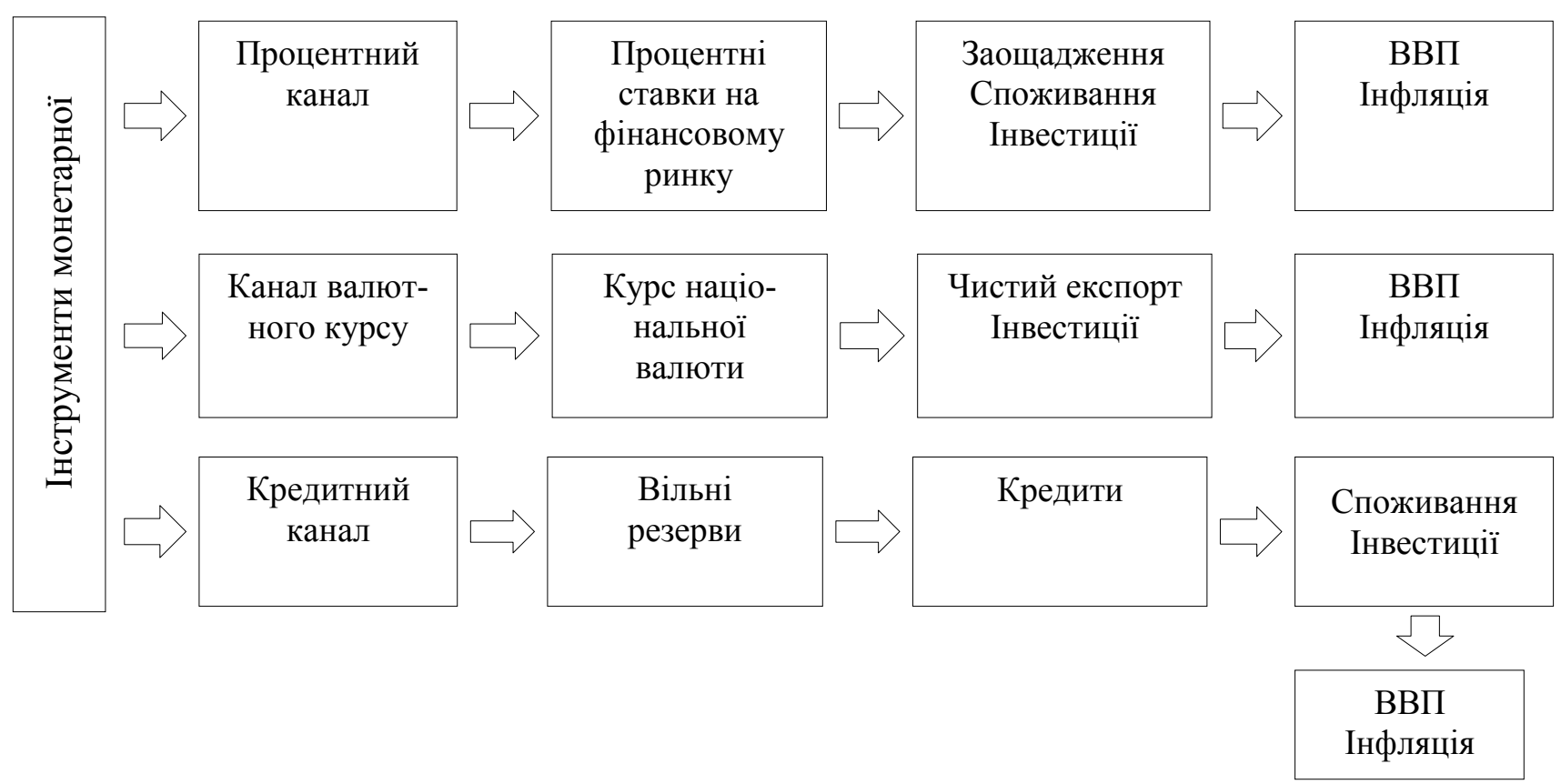

Рис. 2. Схема дії каналів механізму монетарної трансмісії Джерело: [16, с. 89]

Для визначення місця кредитного каналу трансмісійного монетарного механізму в економічному зростанні держави перш за все необхідно провести аналіз стану кредитного ринку України. Потенційні обсяги кредитування реального сектору економіки, за доцільне розпочати із дослідження суб'єктів фінансового ринку, які можуть брати участь у цьому процесі (табл. 1). Як свідчать дані табл. 1, найбільш вагому частку у кредитуванні займають банківські установи, хоча у 2019 р. розмір наданих кредитів зменшилося на 7,65 \% у порівнянні 3 2018 р. При цьому слід відмітити наростаючі темпи зростання обсягів кредитування з боку фінансових компаній та надання фінансового лізингу - 52,5 \% та 24,57 \% відповідно. 
Таблиця 1

Смність ринку кредитних послуг, сформованого банками та небанківськими фінансовими установами, млн. грн.

\begin{tabular}{|l|c|c|c|c|}
\hline \multicolumn{1}{|c|}{ Показники } & 2018 p. & 2019 p. & \multicolumn{2}{|c|}{$\begin{array}{c}\text { Темп приросту } \\
\text { 2019 p./2018 p. }\end{array}$} \\
\cline { 4 - 5 } & & & $\begin{array}{l}\text { абсолютний, } \\
\text { млн. грн. }\end{array}$ & відносний, \% \\
\hline $\begin{array}{l}\text { Банківські установи (кредити } \\
\text { надані клієнтам) }\end{array}$ & 1118860,0 & 1033539,0 & -85321 & $-7,65$ \\
\hline $\begin{array}{l}\text { Фінансові компанії (надання } \\
\text { коштів у позику, в т.ч. і на умовах } \\
\text { фінансового кредиту) }\end{array}$ & 51909,1 & 79176,2 & 27267,1 & 52,5 \\
\hline $\begin{array}{l}\text { Фінансові компанії (надання по- } \\
\text { слуг з факторингу) }\end{array}$ & 48105,0 & 56469,4 & 8364,4 & 17,4 \\
\hline $\begin{array}{l}\text { Фінансовий лізинг (послуги, } \\
\text { надані фінансовими компаніями та } \\
\text { юридичними особами - лізинго- } \\
\text { давцями без статусу фінансової } \\
\text { компанії) }\end{array}$ & 22193,1 & 27645,6 & 5452,5 & 24,57 \\
\hline
\end{tabular}

Джерело: складено автором за матеріалами [17]

Якщо розглядати обсяг кредитів, ресурсів банківської системи направнаданих резидентам у розрізі секторів лена на підтримку корпоративного економіки (табл. 1), то слід відзначи- сектору економіки (табл. 2). ти, що найбільший обсяг кредитних

Таблиця 2

Кредити, надані резидентам України у розрізі секторів економіки за період 2010-2019 pp.

\begin{tabular}{|c|c|c|c|c|c|c|c|c|}
\hline \multirow[b]{2}{*}{$\begin{array}{c}\text { Суб'єкти кре- } \\
\text { дитування }\end{array}$} & \multicolumn{2}{|c|}{2010} & \multicolumn{2}{|c|}{2013} & \multicolumn{2}{|c|}{2016} & \multicolumn{2}{|c|}{2019} \\
\hline & 窇 & 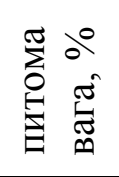 & $\begin{array}{l}\text { 离 } \\
\text { 志 } \\
\text { 帘 }\end{array}$ & 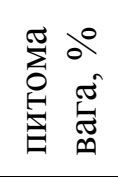 & 窇 & 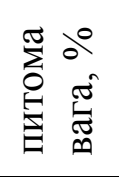 & 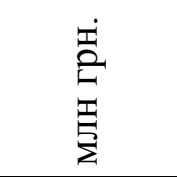 & 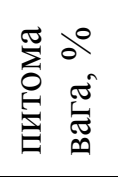 \\
\hline $\begin{array}{c}\text { інші фінансові } \\
\text { корпорації }\end{array}$ & 13430,3 & 1,8 & 19317,5 & 2,1 & 11583,0 & 1,2 & 9577,0 & 1,0 \\
\hline $\begin{array}{c}\text { сектор } \\
\text { загального } \\
\text { державного } \\
\text { управління }\end{array}$ & 8817,3 & 1,2 & 5907,7 & 0,6 & 1429,9 & 0,1 & 4732,5 & 0,5 \\
\hline $\begin{array}{c}\text { нефінансові } \\
\text { корпорації }\end{array}$ & 500960,6 & 68,4 & 691902,8 & 76,0 & 822114,3 & 82,3 & 744647,8 & 76,6 \\
\hline $\begin{array}{c}\text { інші сектори } \\
\text { економіки }\end{array}$ & 209614,6 & 28,6 & 193653,8 & 21,3 & 163554,6 & 16,4 & 212913,6 & 21,9 \\
\hline усього & 732822,8 & 100,0 & 910781,7 & 100,0 & 998681,9 & 100,0 & 971870,8 & 100,0 \\
\hline
\end{tabular}
Джерело: складено автором за матеріалами [17]

Так, у 2019 р. на його підтримку було направлено 744647,8 млн грн., що на 243687,2 млн грн. більше ніж у 2010 р. Хоча, слід констатувати той 
факт, що у 2016 р. було надано кредитів на 77466,5 млн грн. більше, ніж у 2019 р. (при ситуації пікових збитків для банківської системи України). За аналізований період спостерігається у структурній компоненті обсягів кредитування переважання корпоративного бізнесу, ніж домашніх госпо-
Розглядаючи структуру наданих кредитів нефінансовим корпораціям, за цільовим спрямуванням (рис. 3), можна зробити висновок про те, що переважають інші кредити, які пов'язані 3 поточною діяльністю та націлені на поповнення оборотних фондів. дарств.

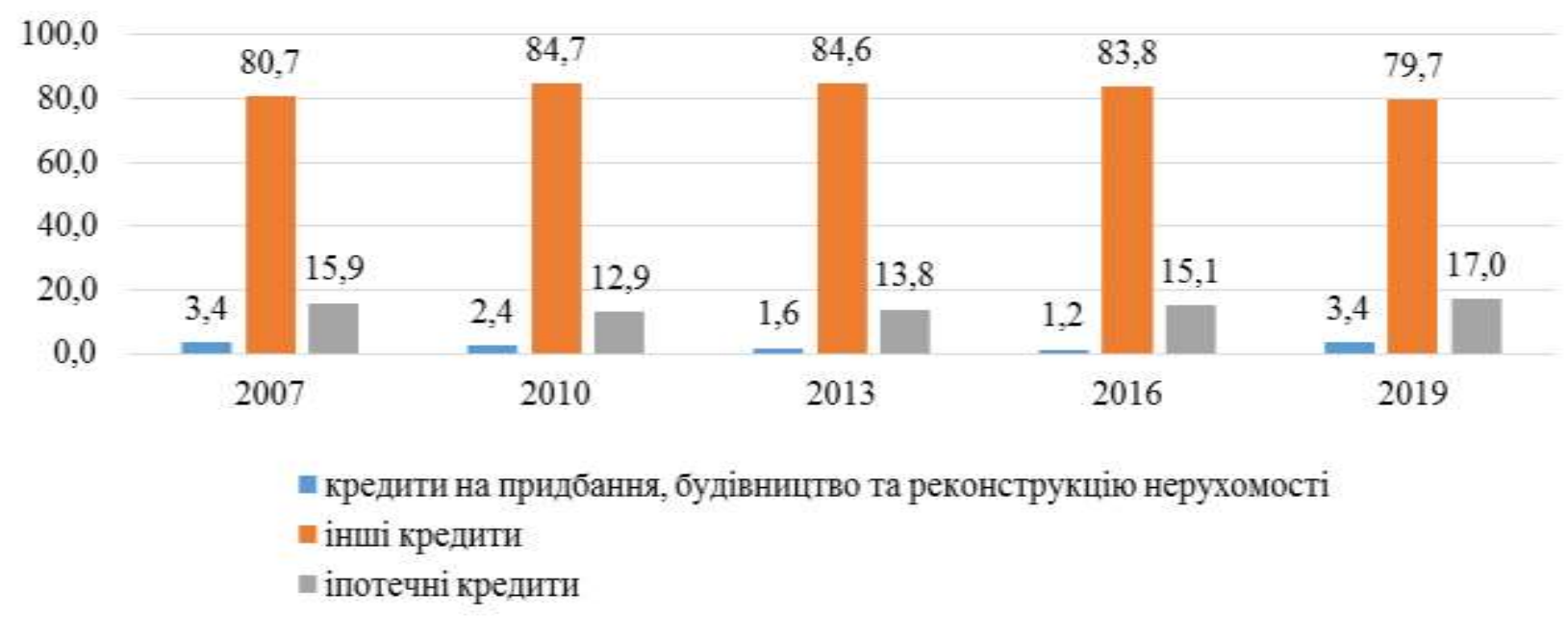

Рис. 3. Структура кредитів, наданих нефінансовим корпораціям за цільовим спрямуванням за період 2007-2019 рр., \%

Джерело: складено автором за матеріалами [17]

Динаміка кредитів, наданих важають короткострокові кредити, які нефінансовим корпораціям за строка- в меншій мірі впливають на розвиток ми (рис. 4), свідчить про те, що пере- корпоративного бізнесу.

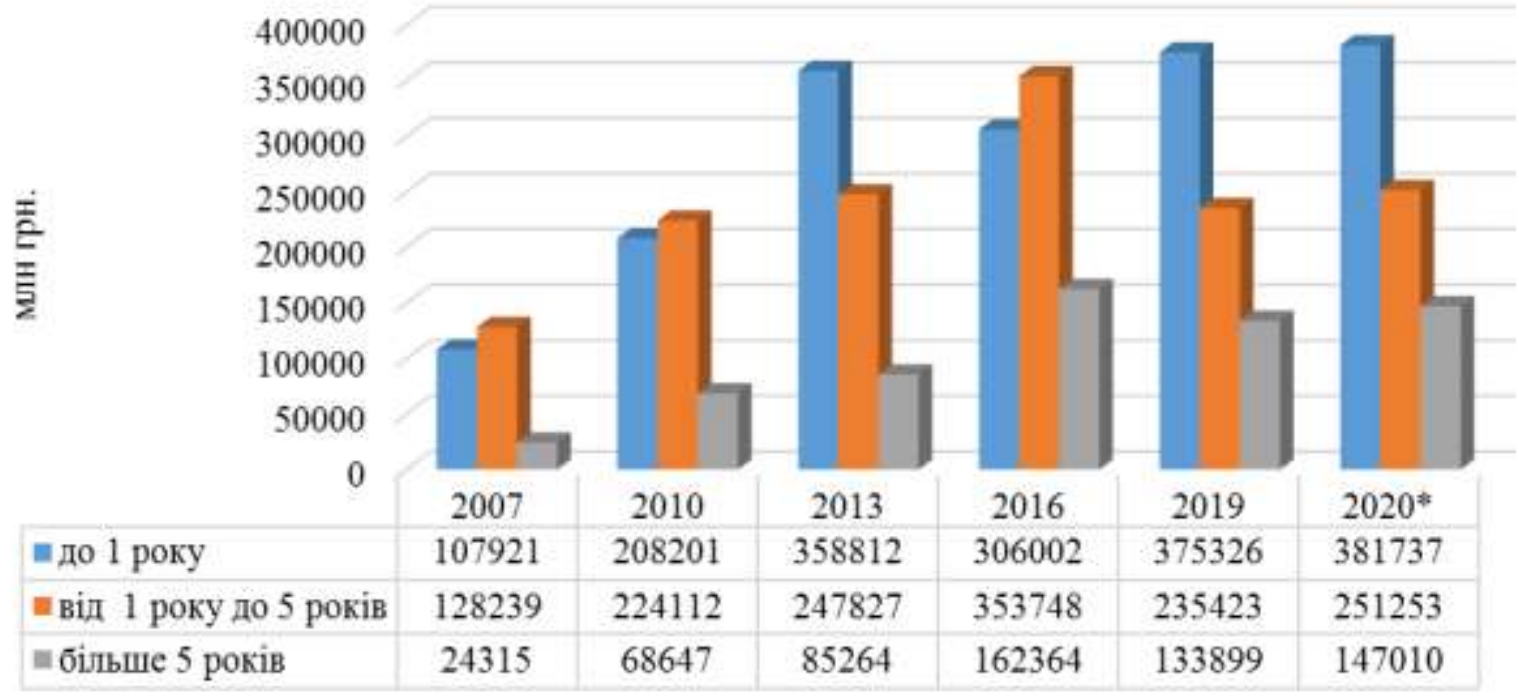

Рис. 4. Динаміка кредитів, наданих нефінансовим корпораціям

за строками, млн грн.

$2020^{*}$ - станом на 01.07 .2020

Джерело: складено автором за матеріалами [17] 
Так, їх сума у 2019 р. склала 375326 млн грн., що у порівнянні 3 попередніми роками має тенденцію до зростання. Про те, слід відзначити позитивну динаміку до зростання наданих кредитів на термін більше ніж п'ять років, що прослідковується на протязі аналізованого періоду. При цьому, 2016 р. слід вважати таким, що супроводжувався не виваженою кредитною політикою банків та дією кредитного каналу трансмісійного монетарного механізму, що і спричинило ситуацію найбільшого обсягу проблемних кредитів за цей період - 89,37 \% (без урахування резервів до капіталу).

Слід також розглянути дію кредитного трансмісійного механізму в залежності від наданих кредитів депозитними корпораціями, відповідно до розміру суб'єкту господарювання (табл. 3).

Таблиця 3 Структура наданих кредитів депозитними корпораціями відповідно до розміру суб'єкту господарювання за період 2017-2020*, \%

\begin{tabular}{|c|c|c|c|c|c|c|c|}
\hline \multirow{2}{*}{ Роки } & \multirow{2}{*}{ 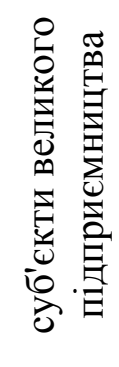 } & \multirow{2}{*}{ 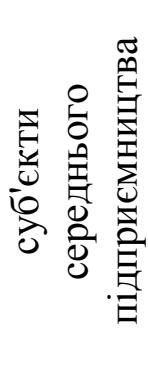 } & \multirow{2}{*}{ 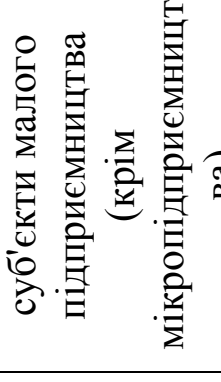 } & \multirow{2}{*}{ 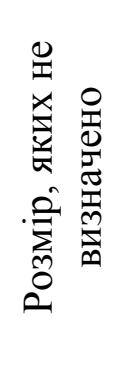 } & \multicolumn{3}{|c|}{ суб'єкти мікропідприємництва } \\
\hline & & & & & $\begin{array}{c}\text { річний дохід } \\
\text { від } 500 \text { тис. } \\
\text { євро до } 2 \\
\text { мЛн. євро } \\
\end{array}$ & $\begin{array}{c}\text { річний дохід } \\
\text { від } 50 \text { тис. } \\
\text { євро до } 500 \\
\text { тис. євро } \\
\end{array}$ & $\begin{array}{c}\text { річний дохід } \\
\text { до } 50 \text { тис. } \\
\text { євро }\end{array}$ \\
\hline \multicolumn{8}{|c|}{ інші фінансові корпорації } \\
\hline 2017 & 12,68 & 8,73 & 22,56 & 20,40 & 16,15 & 3,10 & 16,37 \\
\hline 2018 & 14,43 & 21,39 & 21,66 & 20,13 & 6,46 & 5,62 & 10,31 \\
\hline 2019 & 24,87 & 13,72 & 18,37 & 24,02 & 3,54 & 5,56 & 9,93 \\
\hline $2020 *$ & 17,23 & 16,80 & 21,90 & 22,78 & 3,76 & 10,19 & 7,35 \\
\hline \multicolumn{8}{|c|}{ нефінансові корпорації } \\
\hline 2017 & 37,47 & 25,25 & 13,38 & 10,30 & 3,52 & 2,02 & 8,07 \\
\hline 2018 & 36,07 & 24,72 & 10,99 & 13,19 & 3,42 & 3,19 & 8,43 \\
\hline 2019 & 31,51 & 24,81 & 9,91 & 11,54 & 5,99 & 5,97 & 10,27 \\
\hline $2020 *$ & 29,41 & 27,99 & 10,31 & 10,61 & 6,21 & 5,65 & 9,81 \\
\hline \multicolumn{8}{|c|}{ фізичним особам-підприємцям } \\
\hline 2017 & - & 8,55 & 9,23 & 48,43 & 4,68 & 0,82 & 28,30 \\
\hline 2018 & - & 7,35 & 6,19 & 54,82 & 3,03 & 0,77 & 27,84 \\
\hline 2019 & - & 6,31 & 4,61 & 52,27 & 2,06 & 0,89 & 33,87 \\
\hline $2020 *$ & - & 7,47 & 4,80 & 50,11 & 2,00 & 1,09 & 34,53 \\
\hline
\end{tabular}

2020* - станом на 01.07.2020

Джерело: розраховано автором за матеріалами [17]

Як свідчать дані табл. 3, найбільш стабільна пропозиція кредитних ресурсів спостерігається для суб'єктів великого підприємництва. Розглядаючи кредитування суб'єктів мікропідприємництва, слід відзначити, що перевага надається нефінансовим корпораціям, річний дохід яких складає до 50 тис. євро. та фізичним особам-підприємцям відповідно.

При дослідженні кредитного монетарного трансмісійного механізму за 
доцільне слід розглянути обсяги не- господарювання (табл. 4). працюючих кредитів за суб'єктами

Таблиця 4

Динаміка та структура непрацюючих кредитів за суб'єктами господарювання

\begin{tabular}{|c|c|c|c|c|}
\hline Суб'єкти господарювання & 2017 & 2018 & 2019 & $2020 *$ \\
\hline $\begin{array}{l}\text { Кредити корпоративному сектору, млн } \\
\text { грн. }\end{array}$ & 465842,48 & 490972,63 & 462314,56 & 458335,14 \\
\hline частка непрачүюючих кредитів, \% & 56,95 & 54,76 & 53,50 & 52,99 \\
\hline $\begin{array}{l}\text { Кредити фізичним особам (включно із } \\
\text { фізичними особами-підприємцями), } \\
\text { млн грн. }\end{array}$ & 105836,21 & 140385,50 & 174656,93 & 177654,91 \\
\hline частка непрачюючих кредитів, \% & 26,24 & 23,83 & 19,95 & 21,12 \\
\hline $\begin{array}{l}\text { Міжбанківські кредити, депозити (за } \\
\text { виключенням коррахунків), млн грн. }\end{array}$ & 2537,97 & 4515,88 & 2306,34 & 2176,99 \\
\hline частка непрачюючих кредитів, \% & 36,12 & 19,60 & 34,06 & 37,67 \\
\hline $\begin{array}{l}\text { Кредити органам державної влади та } \\
\text { місцевого самоврядування, млн грн. }\end{array}$ & 1519,26 & 2866,95 & 4716,69 & 5404,50 \\
\hline частка непрачюююих кредитів, \% & 0,69 & 29,22 & 14,48 & 1,40 \\
\hline Усього кредитів, млн грн. & 575735,9 & 638741 & 643994,5 & 643571,5 \\
\hline
\end{tabular}

2020* - станом на 01.07.2020

Джерело: розраховано автором за матеріалами [17]

За даними, наведеними у табл. 4, трального банку на вартість банківсьможна зробити висновок, що ких ресурсів i ставки банківського найбільша питома вага непрацюючих кредитування.

кредитів спостерігається за кредитами корпоративного сектору, яка складає більш ніж $50 \%$. Зазначене свідчить про зменшення обсяг виробництва та про дефіцит фінансових ресурсів для покриття отриманих кредитів.

Ми погоджуємося 3 думкою В. Міщенка, що дієвість кредитного каналу повинна бути забезпечена сприятливим кредитним кліматом, високою ліквідністю банків, постійним й стійким підвищенням коефіцієнта «кредити/ВВП», доступності банківських кредитів та низькою часткою в активах банківської системи проблемних кредитів [15, с.42]. Функціонування кредитного каналу монетарного трансмісійного механізму тісно пов'язане $з$ усіма іншими каналами, особливо процентним, валютним i грошовим. Цей взаємозв'язок має прояв через вплив облікової ставки цен-

За допомогою процентного каналу поширюється вплив на економіку через регулювання процентних ставок, а через них - на сукупний попит і виробництво. Впливаючи на економіку через процентний канал, центральний банк регулює ціну грошей і капіталу як у коротко-, так і довгостроковій перспективі, що позначається на динаміці заощаджень, витрат та інвестицій [8, с. 116].

Слід відзначити, що Національний банк України характеризує вплив облікової ставки на фінансовий ринок та економіку завдяки досягненню ним операційної цілі монетарної політики, яка полягає в утриманні гривневих короткострокових міжбанківських ставок на рівні, близькому до облікової ставки, у межах коридору процентних ставок за інструментами постійного доступу. Однак, ціна банківського креди- 
ту на ринку не знижується адекватно зміні облікової ставки, навіть, 3 урахуванням економічного лагу. Варто додати, що вартість депозитів знизи-

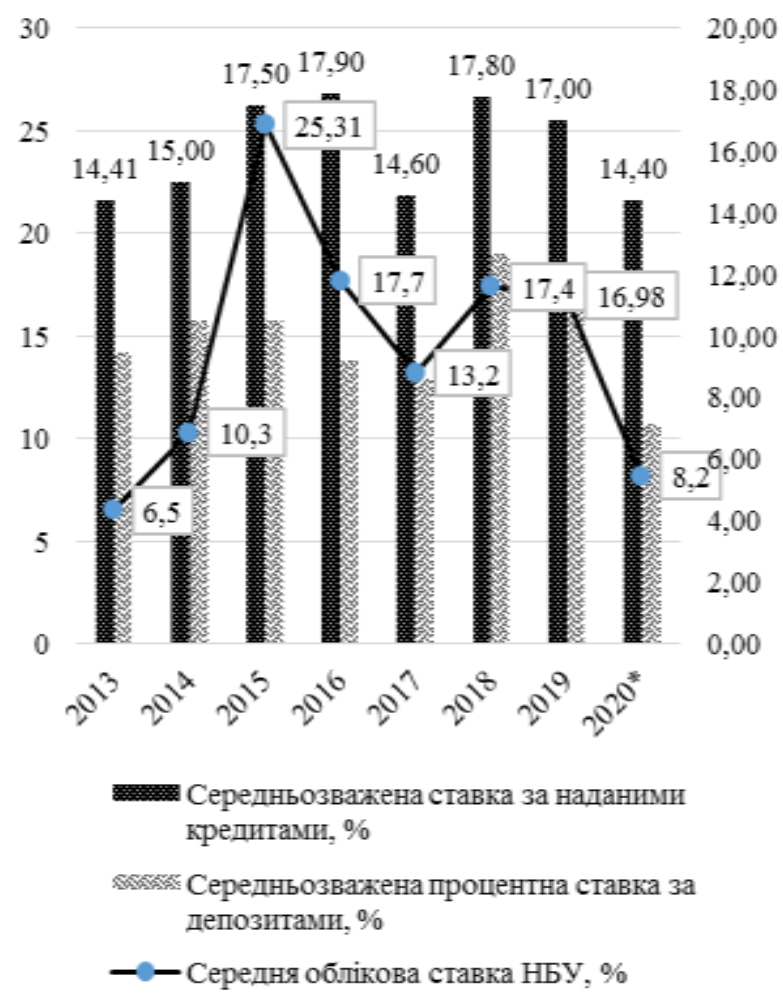

*2020- за перше півріччя

Рис. 5.1 Динаміка середньозваженої облікової ставки, процентних ставок за кредитами та депозитами за період 2013-2020* pp., \% лись значно суттєвіше. Це вказує на недосить ефективну дію кредитного каналу трансмісійного механізму грошово-кредитної політики (рис. 5).

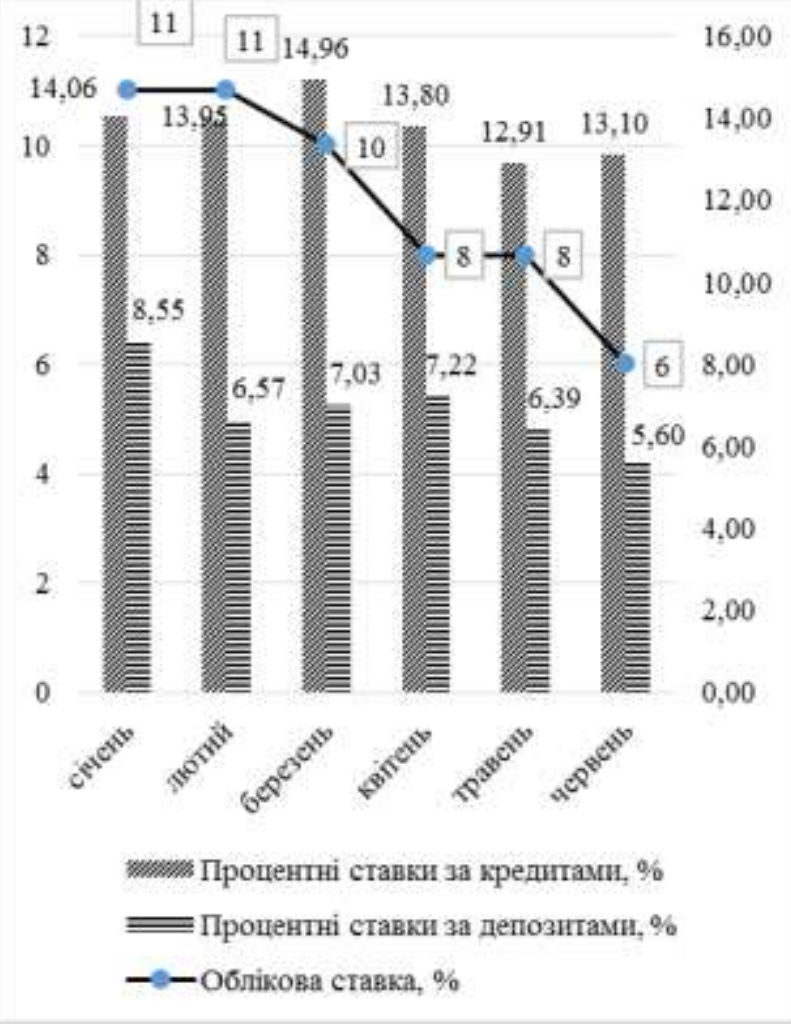

Рис.5.2 Динаміка облікової ставки, процентних ставок за кредитами та депозитами за перше півріччя 2020 р.

Рис. 5 Динаміка облікової ставки, процентних ставок за кредитами та депозитами за період 2013-2020* pp., \%

Джерело: розраховано автором за матеріалами [17]

На сьогодні облікова ставка НБУ складає $6 \%$, Хоча регулятор зазначив, що 3 метою економічного зростання знижуватиме облікову ставку до нейтрального рівня (3-4\%), не зрозумілим залишається за який період це буде досягнуто, зважаючи також на те, що економічний ефект від застосування інструментів грошово-кредитної політики настає через 6-18 місяців.

При цьому слід звернути на дослідження проведене В. Лепушинським, який стверджує, що зміна ключової ставки сьогодні, безсумнівно, впливає на вартість фінансових ресурсів в економіці. Зазначене обгрунтовує стрімким зниженням відсоткових ставок за гривневими кредитами і депозитами вслід за обліковою ставкою [18]. Проте, як ми бачимо із рисунку 5, розрив між середньозваженими ставками за кредитами та ключовою ставкою достатньо значний. В більшій мірі, це стосується наближенню середньозважених процентних ставок за депозитами до рівня ключової. Зазначене свідчить, про існуючі проблемні питання щодо підвищення дієвості 
кредитного та процентного каналів монетарного трансмісійного механізму у забезпеченні економічного зростання держави.

Висновки. На сьогодні, дія кредитного каналу монетарного трансмісійного механізму на економічне зростання в Україні недостатньо ефективна через несприятливий інвестиційний і кредитний клімат, високі ризики, низьку якість i недосконалу структуру кредитного портфеля банків, відсутність платоспроможних позичальників, а також жорсткі цінові й нецінові умови кредитування. Для підвищення його дієвості впершу чергу за необхідне $\epsilon$ проведення когнітивного аналізу стимулювання кредитування економіки банками, на підставі визначення та аналізу основних індикаторів, що характеризують кредитну активність, а саме: індекс розвитку банківської системи; обсяги кредитів резидентам та залучені банками депозити 3 урахуванням впливу інфляції та девальвації гривні; рівень недіючих кредитів; процентна ставка за мобілізаційними операціями та інструментами рефінансування НБУ; визначення потреби у позикових коштах; процентні ставки за новими депозитами та кредитами; девальвація гривні; кількість діючих банків; індекс рівня довіри до банківської системи.

Такий аналіз дозволяє отримати прогнози розвитку альтернативних ситуацій, що значно підвищує якість та знижує ризик прийняття заздалегідь неправильних рішень при визначенні заходів щодо підвищення дієвості кредитного каналу трансмісії, розрахувати наслідки зміни вектору та оцінити доцільність впровадження змін.

Ефект дії кредитного каналу підсилається за умови поліпшення кредит- ного й інвестиційного клімату в державі; підвищення стійкості банківської системи до внутрішніх і зовнішніх шоків; зниження частки проблемних кредитів та підвищення рівня капіталізації банківської системи; поліпшення умов банківського кредитування та посилення механізмів захисту прав кредиторів і вкладників.

В посткризовий період виникає об'єктивна потреба переорієнтації монетарної політики центрального банку 3 рестрикційного напряму на експансивний, який дозволить стимулювати внутрішній попит із боку реального сектору економіки. Зазначене потребує підвищення дієвості поряд 3 кредитним, процентного каналу монетарного трансмісійного механізму на підставі визначення процентної політики Національного банку України, орієнтованої на досягнення внутрішньої рівноваги між рівнями інфляції та економічного зростання. За для досягнення такої рівноваги, за доцільне $\epsilon$ забезпечення позитивного рівня облікової ставки не щодо наявної, а щодо очікуваної інфляції; підвищення ефективності процентної політики за рахунок установлення оптимального коридору ринкових процентних ставок банків за кредитами й депозитами шляхом забезпечення контрольованості ставок грошового ринку; стимулювати кредитування банками реального сектору економіки на основі зниження ставок рефінансування банків для кредитування промисловості до 4-5 \% 3 урахуванням рентабельності високотехнологічних галузей промисловості; забезпечення дієвості ключових елементів інфраструктури грошово-кредитного ринку для сприяння розвитку інституційних 
підходів до управління монетарним трансмісійним механізмом.

Таким чином, для успішного виходу України із кризи за необхідне є формування незалежної фінансової системи країни, орієнтованої на внутрішній кредитний потенціал. Забезпечення економічного зростання держави на довгострокову перспективу повинно відбуватися за рахунок зміни спрямованості монетарних стратегій від антикризових до інноваційних, орієнтованих на підтримку кредитування реального сектору економіки засобами підвищення дієвості каналів монетарного трансмісійного механізму, зокрема кредитного та процентного.

\section{Список використаної літератури}

1. Коваленко В.В.Грошово-кредитна політика та іiі вплив на подолання структурних дисбалансів економіки України. Глобальні та національні проблеми економіки. 2016. № 12. С. 445-449.

2. Єфименко Т. І. Звітування зі сталого розвитку: виклики та шляхи подолання. Фінанси Украӥни. 2019. № 11. С. 9-19. DOI: https://doi.org/10.33763/finukr2019.11.009.

3. Звєряков М. І. Теоретична парадигма сталого розвитку та українські реалії. Економіка Украӥни. 2018. №10. С. 10-31.

4. Минакова Н. В. Устойчивый рост в условиях открытой экономики. США и Канада: экономика, политика, культура. 2018. № 1. С. 59-72.

5. Mishchenko V., Naumenkova S., Mishchenko S., Ivanov V. Inflation and economic growth: The search for a compromise for the Central Bank's monetary policy. Banks and Bank Systems. 2018. Vol. 13. No. 2. P. 153-163. DOI: http://dx.doi.org/10.21511/bbs.13(2).2018.13.

6. Bernanke B. S., Gertler M. Inside the black box: The credit channel of monetary policy transmissionю. Journal of Economic Perspectives. 1995. Vol. 9. Iss. 4. P. 2748.

7. Asongu S. A. A note on the long-run neutrality of monetary policy: new empirics. European Economics Letters. 2014. Vol. 3. Iss. 1. P. 1-6.

8. Прасолова С. П. Вплив процентної політики Національного банку України на стан грошово-кредитної безпеки України та їі економічне зростання. Науковий вісник Полтавського університету економіки і торгівлі. 2018. № 1 (86). C. $115-122$.

9. Кириченко К. В. Дія процентного каналу монетарної трансмісії в умовах трансформативної економіки України. Актуальні проблеми економіки. 2017. № 3 (189). C. 260-266. 
10. Петрик О. I., Дейсан I. М. Неоднорідний вплив монетарних важелів на показники кредитування та економічної активності. Економіка та прогнозування. 2017. № 2. С. 129-152.

11. Про банки і банківську діяльність : Закон України від 07 грудня 2000 р. № 2121-III. URL : http://zakon5.rada.gov.ua/laws/show/2121-14 (дата звернення: 18.08.2020).

12. Міщенко В. I., Науменкова С. В. Банківська система України : проблеми становлення та розвитку. Фінанси України. 2016. № 5. С. 7-33.

13. Коваленко В. В. Вплив грошово-кредитної політики на економічне зростання в Україні. Вісник Української академії банківської справи. 2005. № 1(18). C. 9-14.

14. Міщенко В. І., Петрик О. І., Сомик А. В., Лисенко Р. С. та ін. Монетарний трансмісійний механізм в Україні : науково-аналітичні матеріали. Київ : Національний банк України. Центр наукових досліджень. 2008. Вип. 9. 144 с.

15. Міщенко В. І. Роль і функції монетарного трансмісійного механізму в забезпеченні цінової стабільності. Фінанси України. 2015. № 1. С. 29-46.

16. Коваленко В. В., Шепель Є. В. Впив монетарних чинників на позиціювання інфляційної складової у діяльності банків: методологічні та практичні аспекти оцінювання : монографія. Одеса : Видавництво «Атлант», 2015. 242 с.

17. Офіційний сайт Національного банку України : веб-сайт. URL : https://bank.gov.ua/ua/statistic/supervision-statist/data-supervision\#1/ (дата звернення: 18.08.2020).

18. Лепушинський В. Куди рухаються ставки за гривневими депозитами та кредитами. Економічна правда. 21 вересня 2020. URL : https://www.epravda.com.ua/columns/2020/09/21/665274/?fbclid=IwAR1ESskZPtJg TOmGVfmdj3yJLy2whPOXQKrrDMYyi-blMjJJSX_2sltoZS4 (дата звернення: 18.08.2020). 